\title{
A Historical Overview of Accounting in Romania
}

\author{
DOI NO: 10.5578/JSS.6759
}

\author{
İbrahim Mert $^{1}$
}

\begin{abstract}
The purpose of this historical overview of the development of accounting in Romania was to account for the myriad changes in the Romanian approach to accounting from Ottoman to modern times. The main themes to emerge from the overview were as follows: (a) the development of Romanian accounting was stunted by the immature capitalism and wealth-transfer mentality of the Ottomans; (b) there was rapid and innovative development in Romanian accounting during the early years of Romanian independence; (c) Romania's post-World War Two experience of being a Soviet satellite undid the country's nascent accounting innovations; and (d) Romania has struggled to return to a path of accounting modernity even in the post-Ceausescu era.
\end{abstract}

Keywords: Romania, accounting, economy

\section{Romanya Muhasebe Sistemine Tarihsel Bir Bakış}

\section{Özet}

Muhasebenin Romanya'daki tarihsel gelişmesini inceleyen bu çalışmanın amacı, Osmanlı'dan modern döneme kadar geçen süreçteki önemli değişiklikleri izah etmektir. Ortaya çıkan temel düşünceler şunlardır: (a) Romanya muhasebe sistemi Osmanlı'nın gelişmemiş kapitalizmi ve servet transferi uygulamaları nedeniyle geri kalmuştır; b) Romanya'nın bağımsızlığının ilk yıllarında hızlı ve yenilikçi değişimler gerçekleşmiştir; c) Romanya'nın Sovyet egemenligine girmesine neden olan İkinci Dunya Savaşı tecrübesi ülkenin gelişmeye başlayan muhasebe uygulamalarını durdurdu; ve d) Romanya, Çavuşescu döneminden sonra modern muhasebe hedefine donebilmenin mücadelesini vermektedir.

Anahtar Kelimeler: Romanya, muhasebe, ekonomi

\footnotetext{
${ }^{1}$ Phd. Student, Alexandru Ioan Cuza University, Iaşi, Romania. ibrahimm1508@yahoo.com
} 


\section{Introduction}

Since 1989, Romania has undergone numerous and wide-ranging changes in its accounting practices. These changes are part of Romania's larger experience of economic transformation, which has been profoundly influenced by the end of the Communist regime and entry into the European Union. Romania thus provides rich ground for accounting historians. However, the literature on Romanian accounting transformation is limited. The purpose of this paper is twofold: (a) to summarize what is known of the evolution of Romanian accounting from 1989 onwards and (b) to place these accounting changes in the context of Romanian economic history. One of the special contributions of this article will be the utilization of a broad number of Romanian sources, including sources that cast light on the crucial $19^{\text {th }}$-century evolution of Romanian accounting.

\section{The Evolution of Romanian Accounting: A Chronological-Historical Analysis}

There is broad consensus in the Romanian literature that accounting developed later in Romania than in other Western countries (see for example Demetrescu 1947, 1972; Feleaga, 1999). The reasons for the delayed development of accounting in Romania can be traced to the influence of two larger and interrelated historical forces: Romania's historical dependency on other great powers and the consistent presence of external shocks. In the Middle Ages, the territories that later became Romania contended first with the Kingdom of Hungary and later with the Ottoman Empire (Hentea, 2007). Later, the Austrian Empire and the Austro-Hungarian Empire also exercised hegemony over Romania (Hentea, 2007). It was not until the Treaty of San Stefano, signed in 1878 after the defeat of the Ottoman Empire in the Russo-Turkish War, that Romania gained full independence (Ratliff, 1991). The era of Romanian autonomy was not long-lasted; after the Second World War, Romania was occupied by the Soviet Union, which propped up the Communist regime of Nicolae Ceausescu. The Romanian Communist state was overthrown in the 1989 Romanian Revolution. Romania then transitioned towards free-market democracy, joining the North Atlantic Treaty Organization (NATO) in 2004 and the European Union (EU) in 2007. 


\section{Ottoman Era; The Period up to Communist Economy}

Romania has had a turbulent and heterogeneous history; the country has been subject to repeated and intense external and internal shocks from the Middle Ages onwards. These shocks have exercised a profound influence on the development — or, more accurately, the lack of development — of accounting in Romania. Whereas modern accounting first rose and flourished in an environment of relatively free trade among sovereign entities (whether citystates, countries, or empires), Romania's centuries-long dependency on the Ottoman Empire prevented the maturation of this kind of accounting.

The historical record suggests that Romanians were aware of double-entry accounting at an early date. Romania's geographical position at the center of the Europe, and as the meeting point for several empires, ensured that the country was a conduit for trade. In the course of such trade, Romanians came into contact with Italian merchants who surely knew and employed double-entry book-keeping. However, according to Calu (2005), there is no formal evidence that double-entry bookkeeping was used in Romania until the $18^{\text {th }}$ century. Radu (1995) suggested that, while there were scattered examples of the use of advanced accounting techniques on certain Romanian estates, it was not until the general development of Romanian commerce (which coincided with the marked decline of Ottoman influence in the $18^{\text {th }}$ century) that double-entry bookkeeping became widespread.

These historical data support several conclusions. First, it appears highly likely that Romania's participation in the larger Ottoman economy was based on a combination of agricultural and military activities that did not require the use of more advanced double-entry techniques. Indeed, as Guzel, Oguz, Karatay, and Ocak (2002) have pointed out, the Ottoman accounting system was subtractive rather than double-entry. Second, the decline of the Ottoman Empire and its influence in Europe seemed to open the door for Romania to trade more extensively with its neighbors, thus creating an impetus for improving the national practice of accounting. In particular, as the Romanian territories of Wallachia and Moldavia gained their independence from the Ottoman Empire in 1829, the influence of the Austro-Hungarian Empire created a context for the trade integration of Romania with the remainder of Europe (Kellogg, 1995).

The modern period of accounting in Romania was probably be dated to 1831-1832, when both Wallachia and Moldavia created laws that made the adoption of specific accounting techniques mandatory, at least in the context of public management.. At this time, according to Demetrescu (1972), Romania saw the translation and publication of several foreign books on accounting. The 
first Romanian-language accounting book appears to have been Nichifor's Pravila Comerciala. Not long afterwards, Urzescu and Iarcu made important Romanian-language contributions to the country's incipient accounting literature. These early works were either translated or derivative, and in this sense did not represent direct contributions to Romanian accounting theory, but still laid the framework for the multiplication of original Romanian accounting works at the end of the $19^{\text {th }}$ century.

Romanian accounting underwent a leap forward in the second half of the $19^{\text {th }}$ century. Moldavia and Wallachia were unified in 1859; slightly less than two decades later, Romania had become independent. Romania created a national currency in the late 1860s and set up a national bank in 1880 . Commercial schools, whose curricula included accounting, were set up from about 1860 onwards, and in 1887 the Romanian Code of Commerce required the private use of fixed accounting standards. During this era, many Romanian scholars worked to create a country-specific knowledge and practice of accounting, one that would benefit from the extant European accounting literature while also making room for Romanian accounting concerns, theories, and adaptations. In 1873, Thodor Stefanescu published Contabilitatea in Partida Dubla, held to be the first original Romanian accounting book. Other Romanian accounting theories of the late $19^{\text {th }}$ and early $20^{\text {th }}$ centuries included Petrescu, Pantu, and Lepadatu. These theorists remained highly influenced by the existing European accounting literature but had also begun to create an approach to accounting that reflected Romanian's unique concerns and constraints.

In the early $20^{\text {th }}$ century, developments in Romanian accounting continued apace, driven by a vast expansion in commerce. In 1908, Romania saw the debut of its first accounting journal, Revista Generala de Comert si Contabilitate. Five years later saw the creation of the Academy of High Commercial and Industrial Studies. In 1918, the third Romanian territory of Transylvania was allied to Wallachia and Moldavia. Finally, in 1921, the Organization of Chartered Certified Accountants was created. Each of these developments, in conjunction with the rapidly-expanding Romanian economy, added momentum to the articulation of accounting theory and practice in Romania.

\section{The Period of Communist Economy and Ceausescu Era}

Unfortunately, in 1939, the evolution of accounting in Romania was interrupted by the Second World War. For many European nations, the Second World War was not only a human catastrophe on an unprecedented scale but also a long period of interrupted trade. Nonetheless, several economies 


\section{I.Mert / A Historical Overview of Accounting in Romania}

(including the core economies of what would become the EU) were able to recover. For these economies, the end of the Second World War represented an opportunity to start trading again, especially because the war had depleted some resources while leaving other resources intact, providing powerful motivation for trade (Eichengreen, 1995). For Romania, however, the Second World War was the prelude to occupation by the Soviet Union, which segued into a decadeslong period of Soviet-sponsored Romanian Communism.

Romania's Communist period represented what is essentially an interregnum in the development of Romanian accounting, for a number of reasons. First, as Romania was integrated into the Soviet sphere of influence, the country's burgeoning trade with the remainder of Europe came to a halt. The Soviet economic relationship with Romania was essentially extractive and exploitative (Roper, 2013). Under the aegis of the Council for Mutual Economic Assistance (COMECON), Romania's economic life was largely reduced to what it could provide to, and receive from, the Soviet Union (Roper, 2013). Under these circumstances, there was no need for the practice of advanced accounting, or for the further development of country-specific accounting.

Under Soviet influence, Romanian accounting from the postwar period to the 1989 revolution was characterized by a downward slide in both the importance and robustness of accounting. To begin with, the Communist system set prices and there was thus little need for an accounting system that could distinguish between market value and purchase value. Perhaps more importantly, given that trade was largely limited to COMECON members and, in practice, dictated by the Soviet Union, the purpose of accounting was no longer to provide decision support for independent business and rather to transmit data to the Communist state apparatus (Roper, 2013). During this period, accounting devolved into a form of bookkeeping, responsible for tracking the flow of goods back and forth between the COMECON economies but for little else. Communist economies were profoundly influenced by planning, and, for Romania, accounting came to serve the purpose of demonstrating (often under fallacious pretenses) that a particular plan had been fulfilled (Roper, 2013). Since accounting data were kept secret, there was no external motivation for accuracy or comprehensiveness; even had these data been publicly available, inefficient Communist accounting principles such as price-setting would have distorted the value of the data, and there was no market (consisting, for example, of shareholders) to make decisions on the basis of the data. For all of these reasons, the development of accounting was stifled during the period of Communism in Romania. Without the oxygen of the marketplace, accounting as it had been practiced in pre-war Romania had no basis on which to exist. 
Even during the Communist period, some Romanian theorists continued to add to the body of mainstream accounting knowledge. For example, Marculescu's 1967 study and Dumitrescu's 1973 works both made contributions to Romanian accounting theory. However, the practical effects of these contributions was close to nil, since there was no venue in which companies or the state could practice them.

\section{Post-Ceausescu Era; Establishing the Liberal Economy}

Basically two kinds of developments appeared in this period. The first one can be called as "institutional accounting developments", meaning, decreasing the power of The Ministry of Finance in the regulations of accounting and giving this power to the IAS/IFRS, increasing the number of users of accounting information, accepting training activities in accounting, and switching of State control with independent auditing authorities.

The second development includes establishing accounting regulations for private sector companies, implementing liberal economic accounting principles, rearranging the financial tables and principles accounting concepts such as profit, capital, assets, intangibles and goodwill.

In 1989, Communism fell in Romania. At the time, it had been nearly half a century since Romania had engaged in capitalism; accordingly, Romania could not easily return to its severed tradition of national accounting. There was a pressing need for a form of accounting that could be put into service instantly. For this reason, the post-Communist Romanian state adopted the French accounting system (Tsamenyi \& Uddin, 2009). The French model began to be taught in Romanian institutes of higher education and also served as a pillar of inspiration for the post-Communist accounting legislation passed by the Romanian state (Tsamenyi \& Uddin, 2009).

The fall of Communism did not herald an immediate change in Romanian companies' approach to accounting. It is true that, after the fall of Communism, newly-democratic Romania worked quickly to adopt standards for public accounting and to reintroduce appropriate accounting education. However, Romania had not engaged in capitalism for about 50 years, and newly-formed Romania companies were slow to adopt accounting best practices (Tsamenyi \& Uddin, 2009). During the 1990s, there were also some important changes in the direction of Romanian accounting that created problems for private companies and investors. The French influence that was paramount immediately after 1989 gave way to a more international approach that was heavily influenced by British accounting (Tsamenyi \& Uddin, 2009). In 1997, the World Bank required Romania to adopt what were then known as International Accounting 
Standards (IAS) as one of the conditions for providing the county money (Tsamenyi \& Uddin, 2009). Romania agreed to this condition and received assistance from the United Kingdom in making the transition to IAS, which subsequently gave way to International Financial Reporting Standards (IFRS).

Despite the fact that Romania is now a member of the European Union and a functional, vibrant democracy, the accounting system remains weak in many respects. There persists a system of dual accounting in Romania; just as the country has hesitated to accept the Euro, it has also hesitated to make a strong commitment to IFRS. In addition to the complexity created by the system of dual accounting, Romania is also troubled by the relative lack of accounting experts in IFRS who are also familiar with Romanian accounting. Certain concepts introduced by IFRS are still somewhat alien to the vocabulary of Romania accounting as it evolved, in a fairly haphazard way, after 1989. The top-down efforts of the state to adopt French accounting, followed by IAS and IFRS, did not succeed in convincing businesses to engage in the complex, costly, and culturally-challenging process of adopting these standards.

\section{Conclusion}

Romania has been subject to a number of historical upheavals. In the past 135 years, Romania has become independent, been absorbed into the Soviet satellite system, and re-won its independence. During this journey, Romania has shrugged off the archaic accounting system imposed in Ottoman times and explored the kind of modern accounting systems and approaches necessarily in an environment of free trade. However, although Romania was able to build accounting competence fairly rapidly after emerging from Ottoman rule, the country's more recent experience under Communism continues to cast a shadow over the development of further accounting competence. For two generations, Romania was removed entirely from the fast-moving world of capitalism, and its return to the community of trading nations has been rendered more complicated by the vacillation from the French accounting system to IFRS. Even as Romania struggles to complete the move to IFRS, local companies are, in many instances, continuing to use older forms of accounting left over from the period of French influence. While it certainly seems likely that Romania's long-term future is rooted in the nationwide usage of IFRS, the cumulative impact of Romania's many economic and political shocks will likely lengthen the amount of time necessary for IFRS to become universal. 


\section{References}

CALU, D. (2005). Istorie si dezvoltare privind contabilite din Romania. Bucharest, Romania: Ed. Economica.

DEMETRESCU, C.G. (1947). Istoria critica a literaturii contabile din Romania. Bucharest, Romania: Ed. Socec \& Co.

DEMETRESCU, C.G. (1972). Istoria contabilitatti. Bucharest, Romania: Ed. Stiintifca.

EICHENGREEN, B. (1995). Europe's post-war recovery. Cambridge, U.K.: Cambridge University Press.

EUROPEAN CENTRAL BANK. (2006). Assessment of accounting standards from a financial stability perspective. Retrieved from http://www.ecb.int/pub/pdf/other/assessmentaccountingstandards2006en.pdf

EUROPEAN COMMISSION. (2012). Romania. Retrieved from http://ec.europa.eu/enterprise/policies/sme/business-

environment/files/annexes_accounting_report_2011/romania_en.pdf

FELEAGA, N. (1999). Sisteme contabile comparate. Bucharest, Romania: Ed. Economica.

GUZEL, H.C., Oguz, C., Karatay, O., \& Ocak, M. (2002). The Turks: Ottomans. Istanbul, Turkey: Yeni Turkiye.

HENTEA, C. (2007). Brief Romanian military history. New York, NY: Scarecrow Press.

KELlOGG, F. (1995). The road to Romanian independence. West Lafayette, IN: Purdue University Press.

RADU, R. (1995). Traditii si impliniri in cultura economica si contabila romaneasca in sec. al XIX-lea si al XX-lea. Iasi, Romania: Ed. Junimea.

RATLIFF, W.G. (1991). Treaty of San Stefano. In J.S. Olson \& R. Shadle (Eds.), Historical dictionary of European imperialism (pp. 625-626). Westport, CT: Greenwood Publishing Group

ROPER, S.D. (2013). Romania: The unfinished revolution. New York, NY: Routledge.

TSAMENYI, M. \& Uddin, S. (2009). Accounting in emerging economies. New York, NY: Emerald.

VINALS, J. (2010). Romania: Financial sector stability assessment. Washington, D.C.: International Monetary Fund. 